\title{
The Impact Of the Of the Global Financial Crisis of 2008 on the Nigerian Financial Sector
}

\author{
${ }^{1}$ Ajekwe, Tagher Korna, ${ }^{2}$ Johnmark Mkav. Atagher, ${ }^{3}$ Mwuese. Monica \\ ${ }^{1}$ Dept of Accounting and Finance, University Of Agriculture Makurdi, Benue State, Nigeria \\ ${ }^{2,3}$ Akperan Orshi College of Agriculture Yandev, Benue State, Nigeria
}

\begin{abstract}
The global financial crisis of 2008 has had a disastrous impact on the economies of almost every nation of the world resulting in the collapse of many banking gaint such as the Lehman Brothers Bank in the United States of America. Other manufacturing giants in the car industry in the United States of America, such as the General motors Corporation, Chrysler Corporation and Ford Motors all collapsed, although some of these institutions had to be "bailed out" with public funds by the U.S. government to prevent their total collapse. This scenario has replicated itself in the United Kingdom, France, Germany, Japan and other countries. This paper attempts to look at this phenomenon called the global financial crisis which is seen as a recession and considered as being part of the "business cycle." The paper took an in depth look at the concept of business cycle-which is the upswing in the economy producing booms and busts or recessions of the type witnessed in 2008 and beyond. The paper ended on the genesis of the current global crisis and the impact this has had on national economies and the Nigerian economy in particular, especially on the financial sector.
\end{abstract}

\section{Introduction}

The global economy and indeed the global financial system, has had a history of crises. The Great Depression of the $1930^{\text {ss }}$, the period immediately before and after World War II (i.e $1940^{\mathrm{s}}-1950^{\mathrm{s}}$ ), the OPEC oil crises of the 1970 's the 1980s -1990s also had their share of crisis, and then the current crisis which started in 2008 to date. All these periods of crisis have had grave impacts on the world economy, bringing untold hardship on nations by way of increasing levels of poverty, unemployment, declining productivity, loss of incomes, reduced demand, and general economic downturn.

The current global financial crisis has affected almost every economy, especially western market economies and increasingly every other nation tied to the western economies through trade and other international relations. Most economists describe the current global phenomenon as a recession and recessions are associated with Business Cycles or Trade Cycles.

This paper attempts to look at the impact of the current global financial crisis on the Nigerian financial sector. But before doing this, we shall attempt to consider the issue of Business cycles which do give rise to economic conditions characterized by booms and bursts in national economies which have spill over effects on other national economies as is the case now with the current global financial crisis.

\subsection{Conceptual Framework}

\subsubsection{Business Cycles}

Business cycle or trade cycle (as it is also known) "refers to the phenomenon of cyclical booms and depressions. In a business cycle, there are wave-like fluctuations in aggregate employment, income, and output and price level," Jhingan, (2003:995)

Other economists have given various definitions of the term business cycle according to Jhingan (2003: 995) as follows:

i. "The business cycle in the general sense may be defined as an alternation of periods of prosperity and depression of good and bad trade" (Haberler).

ii. "A trade cycle is composed of periods of good trade characterized by rising prices and low unemployment percentage altering with periods of bade trade characterized by falling prices and high unemployment percentage." (J.A Keynes)

iii. "Business cycles consist of recurring alternation of expansion and contraction in aggregate economic activity the alternating movement in each direction being self - reinforcing and pervading virtually all parts of the economy." (Prof. Gordon).

iv. "Business cycles are a type of fluctuations found in the aggregate activity of nations that organize their work mainly in business enterprises. A cycle consist of expansions occurring at about the sametime in many economic activities followed by similarly general recessions, contractions, and revival which merge into the expansion phase of the next cycles; this sequence of change, is recurrent but not periodic" (Prof. Mitchell). 
The business cycle is essentially a recurring economic condition characterized by periods of boom (prosperity) and burst (recession or depression) in economic activities.

\subsubsection{Types of Business Cycles}

Business cycles are usually classified into the following according to Jhingan, (2003: 996):

i. The short Kitchen Cycle: This is known as the minor cycle and is of approximately 40 month's duration. This is named after British economist Joseph Kitchen following his research in this area.

ii. The long Jugler Cycle: This is also known as the minor cycle. It is defined "as the fluctuation of business activity between successive crises." This cycle is named after French economist Clement Jugler, and has an average duration of nine and half years ( $91 / 2$ years).

iii. The very Long Kondratieff Cycle: This is named after Russian economist, N.D. Kondratieff who in 1925 , came to the conclusion that there are longer waves of cycles of more than 50 years duration, made up of six (6) Jugler cycles.

iv. Building Cycles: This is another type of cycle and relates to the construction of buildings which is of fairly regular duration. This type of cycle's duration is twice that of major cycle and is on an average of 18 years. Building cycles are associated with the name of Warren and Pearson, two American economists who came to this conclusion in world prices and the Building Industry (1937).

v. Kuznets Cycles: This is named after Professor Simon Kuznets American economists who propounded this new cycle, which is known as the secular swing and has a duration of 16-22years.

\subsubsection{Phases of a Business Cycle}

A business cycle is divided into four phase as follows:

i. Expansion or prosperity or the upswing

ii. Recession or upper turning point

iii. Contraction or Depression or Downswing

iv. Revival or Recovery or lower turning point.

\section{Prosperity Phase}

In the prosperity phase, "demand, output, employment and income are at a high level. This tends to raise prices; however, wages, salaries, interest rate, rentals and taxes do not rise in the proportion to the rise in prices. The gap between prices and cost increase the profit margin."

The increase in profit and the prospect of its continuance commonly cause a rapid rise in stock market values. In the course or process of this prosperity phase, the economy reaches a very high level of production, known as the peak or boom.

\section{Recession Phase}

Recession starts with a downward descent from the "peak" which is of a short duration. It marks the turning period during which the forces that make for contraction finally prevail over the forces of expansion. "The outward signs of recession include liquidation or collapse of the stock market, strain in the banking system, and some liquidation of some bank loans, and the beginning of the decline of prices." (Jhingan 2003:996). Recession further results in declining profit margins due to costs overtaking prices, firms closing down, investment, income and demand all decline.

Recession may be mild or severe. This latter degree of recession may lead to a sudden explosive situation emanating from the banking system or the stock exchange, and a panic or crisis occurs, (as is the case now with the crisis in the Nigerian banking system and the capital market that has collapsed).

\section{Depression Phase}

Recession merges into depression which occurs when there is a general decline in economic activities. There is considerable reduction in the production of goods and services, employment, income,, demand and prices. The general decline in economic activities triggers off a fall in bank deposits, credit expansion stops because of the unwillingness of the business community to borrow, the bank rate also falls considerably.

Depression phase is thus characterized by mass unemployment, general fall in prices, profits, wages, interest rates, consumption, expenditure, investment, bank deposit and loans, factories close down; and construction of all types of capital goods, buildings, etc. come to a standstill. The economy is described as being in a trough at this stage,(Jhingan and Stephen, 2004:899-902).

\section{Recovery Phase}

The recovery phase starts following a long period of depression. The "originating forces" or starters may be exogenous or endogenous forces. For instance, durable goods may wear out and need replacement in the economy. This leads to increase in demand. To meet this increase in demand, investment and employment will 
increase. This revives the industry and related capital goods industries. This cumulative process of revival causes levels of employment, income and output to rise in the economy steadily.

This has the effect of causing a rise in prices, increase in profits, business expectations improve and optimism prevails. This leads to increased investment, which leads to increase in demand for bank loans and expansion in credit. The revival phase ultimately enters the prosperity phase.

\subsection{Theories of Business Cycles:}

There are several theories put forward by economists to try and explain the causes of business cycles. The causes of business cycles earlier mention in this paper are based on these theories. We shall only highlight some of these theories here without going into details.

2.1.1 Hawtrey's Monetary Theory: propounded by professor R.G. Hawtery. This theory sees trade cycle as purely a monetary phenomenon. That changes in the flow of monetary demand on the part of businessmen does lead to prosperity or depression in the economy.

2.1.2 Hayek's Monetary Over-investment Theory: Propounded by F.A Hayek. According to him, trade cycles in the economy are caused by inequality between market and natural interest rates.

2.1.3 Schumpeter's Innovations Theory: Developed by Joseph Schumpeter. According to him innovations in the structure of an economy are the source of econ0mic fluctuation.

2.1.4 The Psychological Theory: Developed by Professor A.C. Pigou. This theory attempts to explain the phenomenon of business cycle on the basis of changes in the psychology of industrialists and businessmen.

2.1.5 The Cobweb Theory: Developed independently by Professors H. Schultz of America, J. Tinbergen of the Netherlands and U. Ricci of Italy. But it was Professor N. Kaldor of Cambridge University, England, who used the name Cobweb Theorem because the pattern of movements of prices and outputs resembled a Cobweb.

2.1.6 Samuelson's Model of Business Cycle: Developed by professor P.A. samuelson of MIT. He constructed the multiplier accelerator model oto explain cyclical fluctuations.

2.1.7 Hick's Theory of Business Cycle: Developed by Professor J.R. Hicks.

2.1.8 Keynes's Theory of the Trade: Cycle developed by J.M. Keynes. According to him, trade cycles are 'periodic fluctuations of income, output and employment' (Jhingan and Stephen, 2004:903-924).

\subsection{Genesis of the Current Global Financial Crisis}

The current global financial crisis is variously referred to as global financial crisis, the global economic meltdown, soft prime mortgage crisis etc. all these names refer to the same crisis, which is a recession as earlier mentioned. The current global financial crisis started in the United State of America in 2008, when two mortgage institutions, Freddie Mac and Fannie Mac granted loans to customers to purchase their homes (i.e. estate loans) and those customers defaulted in repaying the loans. That is, those loans became "bad debts" (toxic).

The result of this has been a massive and disastrous effect on the US (United State of America) financial system and economy in general, as this triggered off a massive collapse of the American financial system and economy in general, claiming the investment banking giant, the "Lehman Brother". Most other American Companies, notably those in the car industry like General Motors, Chrysler, etc. became bankrupt, prompting the American government to "bail out" such companies by putting together a "stimulus package" (in billions of dollars) to assist companies and businesses to avert the total collapse of the economy.

As the saying goes, when America snizzes,the world catches a cold! The crosis in America (US) triggered off a global crisis of catastrophic proportions, causing companies and businesses not only in Europe, but also in countries like Japan, China, Russia, India, other Asian countries (Malaysia, Singapore, Thailand, Hong Kong) and Africa etc., to collapse.

Most of these countries have been compelled to "bail out" companies and businesses in their respective jurisdictions to avert the totlzal collapse of their national economies.

\subsection{Impact of Global Financial Crisis on the Various national Economies}

The impact of the global financial crisis on the various national economies is felt in the following areas:

Job Loses: Due to lay offs owing to bankruptcies of companies,fold-ups and shut-downs of companies occasioned by the crisis. In other words, unemployment has been on the increas 3 especially in the US, where the 
number of people applying for social security benefits has been on the increase. The same situation applies to the other major industrialized economies.

i. Loss of Incomes and Livelihoods owing to job loses.

ii. Homelessness and Destitution: The number of people who have lost their homes due to foreclosures especially in the US and other countries have been on the increase.

iii. Stock market Crash (Collapse): In almost all the affected economies, the stock market measures the health of a nation's economy. In almost of all the countries mentioned earlier, stock markets have crashed causing stock prices to fall drastically.

iv. Insolvency (Bankruptcies): By major global corporations like General Motors, Chrysler, etc leading to their collapse or mergers with others etc.

v. Loss of Profitability: Most companies have been declaring losses.

vi. Credit Crunch (Crisis): Banks and other financial institutions no longer grant easy credit. That is, cost of borrowing has increased, making it difficult for most companies to access cash for investment or operational needs, giving rise to the spate of bankruptcies.

vii. Decline in Major Stock Market Indices: (e.g. Dow Jones, Nikkei index, SEP 100 etc.).

viii. Reduction in Value of Equities and commodities: Due to low activities on the stock and commodity exchanges.

ix. $\quad$ Soaring Food Prices: Leading to global hunger and food insecurity.

x. Increase in Crime Rate: In all countries owing to joblessness and the desperate need of individuals to survive, crime rate has been in the increase

xi. Loss of Confidence in the Various National Financial systems and the international financial system in general.

xii. Balance of Payment problems among nations Engaged in trade: The current crisis has not affected all nations in the same way. For instance, China has been able to fair better under this crisis than most other nation's especially Western nations.

xiii. Exchange Rate problem: This is related to balance of payment problems above. The exchange rate of national currencies will be skewed in favour of those not too badly affected by the current crisis like China in our example.

xiv. Protectionism (Trade Restriction) by nations with regard to foreign trade. Protectionist policies have been on the increase as nations struggle to improve their balance of payments positions with their trading partners during this crisis period.

xv. Migration problems: as people try to escape their home countries and illegally migrate to other nations in hopes of finding a beter life. This often puts such illegal immigrants in harm's way as they compete with the locals for the ever dwindling resources. A case in point is the uprising South African youths against immigrants from other African countries in the later part of 2009.

xvi. Low Demand and hence low economic activities due to loss of income resulting from joblessness.

xvii. Liquidity Problems in the Financial Sector especially the banking sub-sector. This has led to credit crunch.

xviii. Greater Government Regulation of the Economy especially the financial sector to forestall the total collapse of this sector and the grave consequence this would have on the economy in general.

\subsection{Impact of the Global Financial Crisis on the Nigerian Financial Sector}

The current global financial crisis has impacted on the Nigerian Financial Sector in the following areas:

Stock market Crash: The Nigerian stock market just like other stock markets across the global crashed, wiping off the equity values of most shares. This has affected both individual and corporate investors adversely as the value of their shares shrunk drastically. Olowe (2009) reported that the stock index fell from 63016.56 points, on April 1, 2008 to 27108.4 points on January 16, 2009.

i. Liquidity and Insolvency Problems: in financial sector have been worsened by the current crisis.

ii. Credit Crunch or Crisis in the sector has also been made worse following the global financial crisis.

iii. Loss of Profitability has become a major problem as most companies are declaring losses instead of profits.

iv. Investment and savings are discouraged due to the dismal outlook of the economy. This is due to the decline in stock market indices as indicated under stock market crash above.

v. Market value of Equities (stocks) has declined thus discouraging investment.

vi. Loss of confidence in the financial system as cases of distress especially in the banking sector have become common place.

vii. Exchange rate and Balance of payments problems in trade relations between Nigeria and other nations are on the increase. 
viii. There is now greater regulation of the financial sector by government (through the appropriate agencies). This is done to forestall the total collapse of this sector and the consequences such a collapse would have on the entire economy. The sacking of 8 bank managements and provision of bailout funds by the Central bank of Nigeria in the last few months of 2009 attest to this (The nation, 3.9.09).

\section{Conclusion}

The current global financial crisis has had tremendous impact on most economies of the world especially those market economies of the West. This impact is not restricted to Western countries alone as it has affected other countries in Europe, Asia, North America and Africa. Most governments reacted to this crisis by providing "'bail out" funds and "stimulus packages"' to cushion the effects of the crisis on their national economies.

The crisis has also affected the Nigerian economy especially the financial sector and the government intervened especially in the wake of the crisis (distress) in the banking system by taking appropriate action to salvage the situation and restore confidence in the financial sector.

\section{Recommendations}

There is need for governments all over the world to build confidence in the global financial system by putting in place policies and programmes that would provide stability in the global financial system.

Following from the above therefore, there is need for greater regulation of the various national economies especially the financial sector to forestall incidents of distress in this sector.

\section{References}

[1]. Jhingan., M.L (2003), Advanced Economic Theory, Delhi: Vrinda Publications (P) Ltd.

[2]. Jhingan. M.L. and J.K. stephed (2004), managerial Economic. Delhi vrinda publications (P) Ltd.

[3]. Oseaze, E.B.(2007), capital markets: African and global. The book house company

[4]. The Nation, September 3,2009.

[5]. Olowe, A. (2009), Financial Management (Concepts Financial System and Business Finance), Lagos: Brierly Jones Nigeria limited.

[6]. Schumpeter, J.A. (1939) Business Cycles in Jhingan, M.L. and J.K. Stephen (2004) Managerial Economics, vrinda publication (P) Ltd

[7]. Keynes, J.M. (1939) Treatise of Money in Jhingan, M.L. and J.K. Stephen (2004), Managerial Economics, vrinda publication (P) Ltd

[8]. Samuelson. P.A. "interaction between the multiplier analysis and principle of acceleration," The Review of Economic Statistics, may, 1939, in M.L. Jhingan and J.K. Stephen (2004), Managerial Economics, Delhi: verinda publication (P)Ltd

[9]. Hawtrey, R.G. (1928, Trade and Credit in Jhingan, M.L. (2003), Advanced Economic Theory, Delhi: publications (P) Ltd.

[10]. The nation newpaper, $3^{\text {rd }}$ September, 2009 